EL MUHASABA: Jurnal Akuntansi (e-Journal)

Volume 10 , No. 2, Tahun 2019

P ISSN: 2086-1249 ; E ISSN: 2442-8922

\title{
PENGEMBARAAN AKUNTAN MENUJU KESADARAN SPIRITUAL: DILIHAT DARI PERSPEKTIF ONTOLOGI, EPISTEMOLOGI, DAN AKSIOLOGI
}

\author{
Driana Leniwati \\ Universitas Muhammadiyah Malang \\ Jl. Raya Tlogomas No.246 Malang Jawa Timur, 65144, Indonesia \\ e-mail:dleniwati@gmail.com
}

Abstract

Modern accounting that emphasizes material and value-free makes accounting toward materialistic, selfish, secularistic and atheistic. This is proven by the many cases of irregularities and manipulations of financial statements carried out by accountants that reflect those characteristics. Meanwhile human assumptions as an opportunistic, greedy and selfish homo economicus increasing this phenomenon. This become the big question to accounting science and the nature of accountants. Accounting as a branch of science has far away from the philosophy. The foothold of the science of accounting is to achieve the true nature of science and attain the ultimate truth of science. This study aims to review accounting from the perspective of ontology, epistemology, axiology and synergize the selfawareness of accountants in relation to humans, nature and God will bring accounting knowledge back to its essence and accountant to God so that accounting science will give benefit to humanity.

Keywords: philosophy of science; self-awareness, ontology, epistemology, axiology

\section{Abstrak}

Ilmu akuntansi modern yang mengedepankan materi dan bebas nilai membuat akuntansi ke arah materialistik, egoistik, sekuleristik dan atheistik. Hal ini dibuktikan dengan banyaknya kasus penyimpangan dan manipulasi laporan keuangan yang dilakukan oleh akuntan yang mencerminkan sifat tersebut diatas. Ditambah dengan asumsi manusia sebagai homo economicus yang oportunistik, serakah dan mementingkan diri sendiri semakin mewarnai kasus-kasus yang terjadi. Fakta yang terjadi mengakibatkan ilmu akuntansi dan hakikat akuntan dipertanyakan. Akuntansi sebagai cabang ilmu pengetahuan sudah meninggalkan filsafatnya. Filsafat ilmu diperlukan sebagai pedoman tempat berpijak dari ilmu akuntansi untuk mencapai hakekat ilmu yang sesungguhnya yaitu mencapai kebenaran ilmu yang hakiki. Penelitian ini bertujuan meninjau akuntansi dari perspektif ontologi, epistemologi, aksiologi serta mensinergikan kesadaran diri yang dimiliki akuntan dalam hubungannya dengan manusia, alam dan Tuhannya akan membawa ilmu akuntansi kembali kepada hakekatnya dan akuntan kepada Tuhannya sehingga ilmu akuntansi akan memberikan kemaslahatan bagi umat manusia.

Kata kunci: filsafat ilmu; kesadaran diri, ontologi, epistemologi, aksiologi 
Driana Leniwati: Pengembaraan Akuntan Menuju Kesadaran Spiritual: Dilihat dari Perspektif Ontologi, Epistemologi, dan Aksiologi

\section{PENDAHULUAN}

Ketika kita bicara tentang filsafat ilmu pengetahuan hal penting yang tidak boleh terlewatkan yang menjadi fokus perhatian adalah pertama, konsep diri (self) yaitu bagaimana seseorang memandang sesuatu terhadap realitas sosial yang ada (Khrisna, 2001; Ewest, 2015). Konsep diri inilah yang membedakan cara pandang seseorang terhadap apa yang akan dilakukan terhadap realitas sosial yang dihadapi. Misalnya didalam dunia perbankan bila dihadapkan kepada nasabah yang memiliki uang yang banyak dan berpotensi, seorang staf pemasaran berbeda cara pandangnya dengan seorang customer service atau auditor internal. Bagi seorang staf pemasaran, bila dihadapkan pada realitas sosial di atas maka yang ada di dalam pikiran seorang staf pemasaran adalah bagaimana caranya agar nasabah tersebut menanamkan seluruh uang mereka ke dalam rekenening bank mereka sehingga staf pemasaran tersebut akan tercapai target yaitu bagaimana mendapatkan nasabah dengan nominal besar sebanyakbanyaknya. Hal ini berbeda dengan seorang customer service yang targetnya adalah bagaimana memberikan pelayanan yang sebaik-baiknya kepada nasabah dengan nominal besar sesuai dengan standar pelayanan yang sudah ditetapkan sehingga dapat meningkatkan kepuasan nasabah meminimalisir komplain di kemudian hari. Sedangkan bagi seorang auditor internal yang ada di benaknya dalam melihat realitas ini adalah menekankan kepada apakah uang yang dimiliki nasabah sudah sesuai dengan transaksi yang wajar dalam arti transaksinya tidak dilakukan bukan transaksi yang mecurigakan dikaitkan dengan money laundry (Kulik, 2005). Hal ini wajar karena target seorang auditor internal perbankan adalah bagaimana bisa menemukan kasus-kasus yang mengarah kepada money laundry ataupun fraud yang terjadi di dalam transaksi nasabah.

Dari ketiga contoh profesi di atas maka sudah jelas bahwa konsep diri sangat menentukan di dalam melihat realitas sosial, kemudian bagaimana dengan konsep diri seorang akuntan? Pribadi atau diri seorang akuntan berbeda beda antara satu dengan yang lainya. Apa dan siapa diri seorang akuntan dan sesungguhnya menyadari siapa diri akuntan itu sendiri. Kesadaran diri yang melekat di diri akuntan yang akan membawa akuntan kepada jati dirinya, darimana akuntan dan kemana akuntan akan menuju itukah hakekat dari 
Driana Leniwati: Pengembaraan Akuntan Menuju Kesadaran Spiritual: Dilihat dari Perspektif Ontologi, Epistemologi, dan Aksiologi

akuntan didalam menerapkan ilmu akuntansi di lingkungannya, baik di lingkungan kerja maupun di lingkungan masyarakat. Konsep diri seorang akuntan tidak terlepas dari ilmu akuntansi yang membawanya. Gotsis dan Kortezi (2008) menjelakan bahwa philosophy of science sangat mempengaruhi cara pandang seseorang di dalam melihat dan bertindak. Begitu pula dengan ilmu akuntansi tidak terlepas dari filsafat ilmu. Filsafat ilmu yang membuat ilmu tersebut lebih mengarah ke arah ilmu yang wise. Ilmu pengetahuan yang seperti apa yang merupakan ilmu yang benar dipelajari di dalam filsafat.

Pada penelitian ini penulis akan membahas bagaimana relevansi filsafat Ilmu pengetahuan yang dikaitkan dengan kajian praktik akuntansi dengan melihat akuntansi dari berbagai perspektif yaitu ontologi, epistemologi dan aksiologi. Selain itu juga akan dibahas implikasi hakekat akuntan dengan berbagai macam kesadaran yang melekat di dirinya yang secara spesifik menggambarkan hubungan akuntansi dengan manusia, akuntansi dengan alam dan hubungan akuntansi dengan Tuhan.

\section{KAJIAN PUSTAKA}

\section{Filsafat Ilmu dan Akuntansi}

Pengetahuan (knowledge) berbeda dengan ilmu pengetahuan (science). Pengetahuan adalah sesuatu yang bisa ketahui melalui inderawi. Sedangkan ilmu pengetahuan (science) adalah bagian dari pengetahuan atau filsafat ilmu pengetahuan adalah bagian dari filsafat ilmu (epistemologi). Filsafat ilmu menurut Liang Gie (1987) dalam Gotsis dan Kortezi (2008) adalah segenap pemikiran reflektif pada persoalan-persoalan mengenai segala hal yang menyangkut landasan ilmu maupun hubungan ilmu dengan segala segi kehidupan manusia.

Filsafat ilmu adalah dasar bagi ilmu-ilmu yang ada. Filsafat ilmu merupakan tempat berpijak bagi ilmu-ilmu lain. Dengan filsafat manusia selalu berpikir lebih mendalam, menyeluruh dan kritis untuk memperoleh kepastian dan kebenaran yang hakiki. Oleh karena itu dengan filsafat ilmu akan mengembangkan ilmu-ilmu yang tidak hanya dari segi pandang ilmu itu sendiri, tetapi juga melihat pada hakekat ilmu dengan pengetahuan yang lain. Contoh: Ilmu akuntansi yang ada sekarang ini sudah berkembang lebih luas. Ilmu akuntansi tidak lagi hanya mempersoalkan perhitungan debet dan kredit saja di 
Driana Leniwati: Pengembaraan Akuntan Menuju Kesadaran Spiritual: Dilihat dari Perspektif Ontologi, Epistemologi, dan Aksiologi

dalam laporan keuangan tetapi ilmu akuntansi sudah mengarah kepada ilmuilmu sosial yang berhubungan dengan realitas sosial di mana manusia sebagai obyek dari yang ditelaah. Manusia dengan segala perilaku, prinsip dan kegiatannya itulah yang akhirnya melahirkan ilmu akuntansi baru seperti akuntansi syariah yang menekankan kepada proses akuntansi yang bermuatan spiritual (Bouckaerti dan Zsolnai, 2012; Brophy, 2015).

Akuntansi syariah hadir sebagai ilmu akuntansi yang melihat akuntansi tidak secara duniawi tetapi juga akuntansi yang dalam prosesnya mengedepankan nilai-nilai syariah seperti penentuan bagi hasil sebagai pengganti tingkat bunga kepada nasabah bank. Akuntansi pertanggungjawaban sosial (Social Responsibility Accounting) juga hadir untuk melihat akuntansi yang mempunyai tanggung jawab sosial terhadap lingkungan sekitarnya dan sebagainya. Kehadiran ranting-ranting baru ilmu akuntansi ini semua bertujuan untuk mencari kebenaran ilmu pengetahuan yang hakiki yang berusaha menyatukan manusia, alam dan Tuhan sehingga ilmu akuntansi akan lebih bermakna di dalam pelaksanaannya. Semua gebrakan ini dilandasai oleh filsafat ilmu yang selalu mencari kebenaran ilmu yang hakiki.

\section{Akuntansi Dalam Perspektif Ontologi}

Ontologi adalah teori of being atau teori keberadan. Ontologi adalah asumsi filosofis yang berkaitan dengan pandangan manusia tentang realitas yatu membicarakan sesuatu dibalik yang tampak (Suriasumantri, 1993). Ontologi berkaitan dengan obyek apa yang ingin dipelajari baik obyek material maupun obyek formal dan bagaimana hubungan antara obyek tadi dengan daya tangkap manusia yang membuahkan pengetahuan. Obyek material adalah segala sesuatu (materi) yang dipelajari oleh ilmu pengetahuan, sedangkan obyek formal adalah sudut pandang suatu ilmu pengetahuan dalam mempelajari obyek materinya.

Berdasarkan obyek yang dipelajari penulis menfokuskan pada dua aliran filsafat yaitu aliran realisme dan aliran idealism (Mc Pherson, 2015). Pertama, realism yang dicetuskan pertama kali oleh Socrates yaitu aliran yang menyatakan obyek-obyek yang diketahui adalah nyata dalam dirinya sendiri. Obyek tersebut tidak tergantung pada yang mengetahui, atau tidak tergantung pada pikiran. Pikiran dan dunia luar saling berinteraksi, tetapi interaksi ini tidak 
Driana Leniwati: Pengembaraan Akuntan Menuju Kesadaran Spiritual: Dilihat dari Perspektif Ontologi, Epistemologi, dan Aksiologi

mempengaruhi sifat dasar dunia (Meng, 2016). Dunia akan tetap ada sebelum pikiran menyadari dan dunia akan tetap ada setelah pikiran menyadari. Jadi dengan pernyataan di atas maka dapat disimpulkan yang obyek yang dipelajari adalah materi. Segala sesuatu yang tidak berhubungan dengan materi seperti sesuatu yang tidak nyata yang meliputi mental dan spiritual bukan merupakan obyek dari yang dipelajari. Contoh: ketika seseorang buruh mendapatkan gaji yang terlihat adalah dia senyum karena senang mendapatkan gaji, padahal kemungkinan dibalik senyumnya ada makna lain yang lebih dari sekedar materi (gaji) yang didapat yaitu kepuasan karena telah bekerja dengan baik sehingga dia puas dengan gaji yang diterima (mental) dan rasa syukur atas nikmat Allah yang diberikan kepadanya dalam bentuk gaji (spiritual). Bila dikaitkan dengan obyek formal yaitu sudut pandang suatu ilmu pengetahuan dalam mempelajari obyek materinya maka aliran realism menganut sudut pandang/paradigma positivist.

Paradigma positivist merupakan paradigma yang muncul paling awal dalam dunia ilmu pengetahuan dimana keyakinan dasar pada aliran ini menyatakan bahwa realitas berada (exist) dalam kenyataan dan berjalan sesuai dengan hukum alam (natural law). Aliran ini berupaya mengungkapkan kebenaran realitas yang ada, dan bagaimana realitas tersebut senyatanya berjalan. Paradigma positivist sebenarnya mengadop dari ilmu alam (natural science) dimana Auguste Comte melalui karyanya, The Course of Positive Philosopy berusaha menerapkan metode-metode dengan presisi kuantitatif ilmu-ilmu alam (terutama fisika, matematika dan biologi) untuk menemukan prinsip-prinsip keteraturan dan perubahan di dalam masyarakat sehingga menghasilkan susunan pengetahuan baru yang bisa dipakai untuk mereorganisasi masyarakat demi perbaikan umat manusia.

Salah satu ciri paling penting dari paradigma ini adalah keyakinan bahwa fenomena sosial itu memilki pola dan tunduk pada hukum deterministis seperti layaknya hukum-hukum yang mengatur ilmu alam. Jadi yang merupakan obyek yang dipelajari dalam paradigma positivist adalah fenomena sosial yang nyata dan bersifat materi dan bagaimana inderawi menangkap obyek sehinga membuahkan ilmu pengetahuan. Contoh: fenomena sosial yang terjadi di perbankan misalkan ketika suku bunga deposito naik maka semakin banyak 
Driana Leniwati: Pengembaraan Akuntan Menuju Kesadaran Spiritual: Dilihat dari Perspektif Ontologi, Epistemologi, dan Aksiologi

nasabah yang membuka rekening deposito di bank. Fenomena ini dapat ditangkap oleh inderawi dan ada hubungan materi antara suku bunga dengan banyaknya nasabah yang pada akhirnya akan meningkatkan laba perusahaan. Fenomena sosial ini bisa membuahkan ilmu pengetahuan apabila dilakukan penelitian secara mendalam terhadap fenomena ini misalkan untuk melihat pengaruh suku bunga deposito terhadap peningkatan jumlah nasabah bank.

Kedua, idealism yaitu aliran filsafat ilmu yang mengedepankan ide sebagai obyek. Semua bentuk realita adalah hasil pemikiran dari ide. Misalkan ketika kita melihat wujud handphone atau alat teknologi lainnya sebenarnya itu adalah hasil dari ide atau pemikiran manusia yang diwujudkan idenya berupa alat yaitu handphone. Pencetus dari aliran ini adalah Plato. Idealism muncul karena adanya feed back dari realism yang mengagungkan materi sebagai obyek yang dipelajari. Aliran ini menyatakan bahwa ide akan selalu ada ketika manusia hidup dan berpikir. Dengan berjalannya waktu idealism akan selalu ada sepanjang ada kehidupan. Obyek material dari idealism adalah pemikiran/ide/gagasan. Pemikiran/ide/gagasan manusia yang bersifat abstrak tidak bisa dipegang dan tidak real inilah yang bisa melihat fenemona sosial lebih berwarna, lebih subyektif bahkan lebih beragam tergantung dari sudut pandang manusia itu sendiri. Contoh: produk bank seperti e-money (elektronik money) yang berwujud kartu yang launching beberapa bulan terakhir ini kita melihat tidak hanya sekedar melihat kartu saja sebagai wujudnya tetapi lebih dari itu e-money merupakan pemikiran/ide/gagasan manusia yang bersifat tidal real atas fenomena sosial yang terjadi saat ini dimana manusia selalu menginginkan kepraktisan, kecepatan dan kemudahan di dalam melakukan transaksi keuangan. Sedangkan bila dikaitkan dengan obyek formal yaitu sudut pandang suatu ilmu pengetahuan dalam mempelajari obyek materinya maka aliran idealism adalah kebalikan dari paham positivist yaitu menganut sudut pandang atau paradigma non positivist dengan berbagai paradigma yaitu interpretivist, critical postmodernist dan spiritualist. Pemikiran/ide/gagasan inilah yang akan terus mengembangkan ilmu pengetahuan yang benar dengan kesadaran manusia yang selalu mencari jati dirinya untuk menjadi lebih bermakna ke arah spiritual. 
Driana Leniwati: Pengembaraan Akuntan Menuju Kesadaran Spiritual: Dilihat dari Perspektif Ontologi, Epistemologi, dan Aksiologi

Berbeda dengan realism, idealism lebih mengarah kepada social science yaitu lebih melihat fenomena sosial yang terjadi itu adalah hubungan interaksi antara berbagai macam manusia yang memiliki pemikiran/ide/gagasan bahkan makna yang berbeda-beda walaupun pada waktu dan tempat yang sama. Fenomena sosial dipahami secara subyektif. Contoh: Pencapaian Laba yang tinggi pada akhir tahun di bank memberikan makna yang berbeda-beda terhadap karyawannya. Bagi seorang karyawan dengan level asisten ke bawah, makna laba diartikan sebagai materi dikaitkan dengan bonus tahunan yang akan mereka dapatkan ketika laba meningkat. Berbeda halnya makna laba bagi level manager hingga pimpinan tertinggi, makna laba yang tinggi lebih diartikan sebagai leadership yaitu tanggung jawab yang lebih besar dalam memimpin karyawan dibawahnya agar terus dapat mempertahankan dan meningkatkan laba di tahun berikutnya. Makna laba sebagai materi bukan merupakan prioritas utama mereka lagi. Ada tanggung jawab leadership yang lebih besar dibalik makna laba disamping sekedar bonus (materi).

Kedua aliran filsafat inilah yang akan membawa ilmu akuntansi kepada pemahaman tentang kebenaran ilmu pengetahuan serta pengembangan ilmu yang benar.

\section{Akuntansi Dalam Perspektif Epistemologi}

Epistemologi adalah teori of knowledge yang diartikan sebagai teori pengetahuan yang benar. Epistemologi adalah cabang dari filsafat yang mengkaji tentang pengetahuan terutama dari segi apa yang dimaksud dengan pengetahuan, jenis-jenis pengetahuan dan asal mula pengetahuan (Suriasumantri, 1993). Ada beberapa aliran filsafat untuk memperoleh pengetahuan yaitu pertama, positivism berpendapat bahwa kepercayaankepercayaan yang bersifat dogmatis harus digantikan dengan pengetahuan yang berdasarkan fakta dan apapun yang berada di luar pengalaman tidak perlu diperhatikan. Dalam menemukan kebenaran, pendekatan positivist harus terukur, teramati, empiris dan bertujuan membuat generalisasi. Auguste Comte memberikan pemaknaan bahwa positivist menunjuk pada sesuatu yang konkret, pasti, jelas dan bermanfaat. Setiap ilmu bebas nilai (value free) dalam menghasilkan ilmu pengetahuan. Nilai-nilai lain seperti etika, moral dan 
Driana Leniwati: Pengembaraan Akuntan Menuju Kesadaran Spiritual: Dilihat dari Perspektif Ontologi, Epistemologi, dan Aksiologi

spiritual tidak diperhatikan dalam aliran ini. Cara pandang dalam aliran inilah yang membuat manusia dengan asumsi homo economicus semakin bersifat materialistik. Contoh: Laporan Keuangan perusahaan semua diukur dengan materi. Setiap pos-pos yang terdapat di dalam Laporan Keuangan hanya difokuskan kepada berapa nominal yang diperoleh yang dihitung melalui statistik dan matematika. Laba sebagai ukuran kinerja dari perusahaan membuat para pelaku bisnis berlomba-lomba mengejar laba yang setinggi-tingginya dengan mengesampingkan nilai-nilai etika, moral dan spiritual dalam proses pencapaiannya. Yang ada dalam pikiran mereka adalah bagaimana meningkatkan laba yang setinggi-tinginya sehingga akan akan terlihat "cantik" di dalam Laporan Keuangan perusahaan yang otomatis akan memberikan pengaruh (materi) kepada perusahaan atas penilaian investor, kreditor dan para penguna Laporan Keuangan lainnya. Terlebih asumsi manusia sebagai binatang ekonomi (homo economicus) yang selalu bersifat opportunistik, serakah dan tidak bermoral yang selalu memikirkan materi di atas segalanya akan menghalalkan segala cara dalam pencapaian laba. Kasus Enron yang membuat preseden buruk terhadap akuntan semakin mempertanyakan hakekat akuntan yang sebenarnya karena kasus yang terjadi bukan merupakan kecelakaan bisnis belaka tetapi merupakan bentuk keserakahan dari para akuntan yang sudah kehilangan jati dirinya yang lebih fokus pada materialistik (Kulik, 2005).

Kedua, rasionalism dimana aliran ini berupaya memperoleh kebenaran yang didasarkan pada logika. Segala pengertian, pengetahuan dan kebenaran bersumber dari akal, budi atau rasio. Kedaulatan rasio diakui sepenuhnya dengan sama sekali menyisihkan panca indra, sebab pengetahuan indera hanya menyesatkan saja. Menurut aliran ini semua ilmu berasal dari pemahaman intelektual manusia yang dibangun atas kemampuan berargumentasi secara logis. Bukan dibangun atas pengalaman empiris tetapi lebih pada pemaknaan empiris yang didukung oleh data empiris yang relevan. Dalam kenyataan ada pengetahuan tertentu yang bisa dibangun oleh manusia tanpa harus atau tidak bisa mempersepsinya dengan indra terlebih dahulu manusia bisa membangun pengetahuan. Bertitik tolak dari pandangan seperti ini, maka rasionalisme menempatkan akal adalah salah satu sumber ilmu pengetahuan dan dalam pandangan moderatnya berpendirian bahwa manusia memiliki potensi 
Driana Leniwati: Pengembaraan Akuntan Menuju Kesadaran Spiritual: Dilihat dari Perspektif Ontologi, Epistemologi, dan Aksiologi

mengetahui. Contoh: dalam pencapaian Laba perusahaan, aliran ini mengganggap bahwa laba terjadi karena ada pendapatan yang diperoleh perusahaan dan biaya yang dikeluarkan perusahaan. padahal kalau kita mencoba menelaah lebih lanjut pencapaian laba perusahaan tidak terlepas juga dari "tangan-tangan Tuhan" misalkan doa yag selalu dipanjatkan karyawan untuk kemakmuran perusahaan atau kegiatan spiritual perusahaan misalnya kegiatan rutin berbagi dengan masyarakat sekitar perusahaan yang tidak mampu sebagai wujud rasa sukur atas laba yang diperoleh perusahaan dan kegiatan rutin spiritual lainnya. Nilai-nilai yang tidak rasional inilah yang tidak bisa dimasukkan ke dalam akal yang tidak diakui oleh para penganut rasionalism sehingga aliran ini akan membawa manusia kepada kebenaran ilmu yang sekuleristik dan atheistik.

Ketiga, empirism dimana aliran ini berlawanan dengan rasionalism. Sumber pangkal pengetahuan bukanlah akal budi tetapi pengalaman atau indera. Aliran ini memandang bahwa filsafat tidak ada gunanya dalam hidup. Sedangkan yang berguna adalah ilmu yang diperoleh melalui indera (pengalaman). Atau dengan kata lain dalam memperoleh kebenaran adalah dengan meningkatkan pengalaman (indera) sehingga kebenarannya adalah aposteriori. Pengetahuan diperoleh dengan jalan menggunakan dan membandingkan gagasan-gagasan yang diperoleh dari penginderaan dengan refleksinya. Berbeda dengan positivist, akal manusia hanya merupakan tempat menampung yang secara pasif menerima hasil penginderaan manusia. Gejala-gejala alamiah bersifat konkret dan diungkap lewat penginderaan dan bila ditelaah lebih lanjut akan menghasilkan pengetahuan dengan karakteristik tertentu. Contoh: di dalam ilmu alam (natural science) secara indera manusia dan seisinya di bumi ini bisa berpijak karena ada gaya tarik gravitasi. Begitu juga terjadinya fenomena alam tentang gerhana bulan, gerhana matahari dan lainnya bisa diungkap lewat penginderaan dan menghasilkan ilmu pengetahuan alam. Aliran ini memperoleh kebenaran ilmu dengan meningkatkan pengalaman dan indera misal manusia bisa berjalan di bulan merupakan hasil dari peningkatan ilmu melalui indera. Padahal semua kejadian alam dan semua yang ditangkap melalui indera sebenarnya adalah atas kuasa dari Tuhan. Hal-hal yang tidak nyata/konkret ini tidak diakui dalam aliran ini. Contoh lain dalam ilmu akuntansi misal 
Driana Leniwati: Pengembaraan Akuntan Menuju Kesadaran Spiritual: Dilihat dari Perspektif Ontologi, Epistemologi, dan Aksiologi

pencapaian laba yang tinggi yang diperoleh perusahaan merupakan hasil dari strategi, leadership atau hasil kerja keras dari karyawan dan sebagainya yang bersifat nyata dan bisa diungkap lewat indera. Tetapi pencapaian laba yang tinggi sebenarnya juga hasil campur tangan Allah sebagai pemilik alam semesta ini atas rejeki yang dilimpahkan kepada makhluknya. Hal-hal yang tidak nyata yang tidak bisa diukur itu tidak diakui dalam aliran ini. Aliran ini hanya melihat hal-hal yang empiris saja sehingga ilmu yang didapat bisa memberikan kebenaran yang bersifat atheistik yaitu hanya memikirkan duniawi di dalam penerapannya.

Keempat, critical mencoba mengatasi perdebatan antara empirisme dan rasionalisme. Aliran ini berusaha menjawab persoalan pengetahuan. Salah satu tokohnya adalah Immanuel Kant. Menurut Kant, waktu dan ruang adalah dua bentuk pengamatan. Akal menerima bahan pengetahuan dari empiris (hasil pengamatan), bahan-bahan yang berasal dari pengamatan ini masih kacau, kemudian diatur oleh akal dalam bentuk pengamatan yakni ruang dan waktu. Bahan-bahan tersebut diurutkan, pengamatan merupakan permulaan pengetahuan, sedangkan pengolahan oleh akal merupakan pembentukannya. Critical memandang bahwa realitas sebagai hal yang memang ada dalam kenyataan sesuai dengan hukum alam, namun menurut aliran ini sesuatu hal yang tidak bisa dirasio atau dilihat secara benar bagi manusia untuk melihat realitas secara besar hanya dengan melalui pengamatan manusia. Oleh sebab itu critical sangat menekankan konsep subyektifitas dalam menemukan suatu ilmu pengetahuan.

\section{Akuntansi Dalam Perspektif Aksiologi}

Setiap ilmu atau ajaran dalam kelahirannya selalu didasari oleh nilai-nilai tertentu. Diskusi antara Karl Popper dan Habermas banyak menjelaskan perspektif tersebut (Driscoll \& McKee, 2007). Popper terbiasa menggunakan ilmu alam di mana menganut bebas nilai (value free). Yang ada adalah sesuatu yang bisa diukur, sesuatu yang nyata dan obyektif. Sedangkan Habermas mengatakan bahwa ilmu harus bernilai, harus bersifat sebagai emansipatoris terhadap kaum tertindas dan bermanfaat buat sesama. Contoh: misalkan dalam penelitian yang ingin melihat hubungan antara laba yang tinggi dengan motivasi pegawai, aliran 
Driana Leniwati: Pengembaraan Akuntan Menuju Kesadaran Spiritual: Dilihat dari Perspektif Ontologi, Epistemologi, dan Aksiologi

Popper mengakui laba perusahaan yang tinggi itu akibat dari motivasi kerja karyawan yang tinggi. Motivasi yang tinggi diakibatkan karena insentif, bonus ataupun bentuk materi lainnya. Ada hubungan yang positif diantara keduanya. Popper tidak melihat apa yang menyertai dari motivasi kerja karyawan tersebut dan nilai-nilai apa yang menyertainya sehingga tercapai laba yang tinggi. Jadi hanya melihat sesuatu yang nampak yang bisa diukur dan bebas nilai. Berbeda dengan aliran Habermass yang mengakui nilai di dalam setiap obyek yang diteliti dan tidak menganut bebas nilai. Dalam contoh di atas motivasi kerja karyawan menurut penganut aliran ini tidak hanya dipengaruhi oleh material saja tetapi juga ada nilai-nilai etika di dalamnya yaitu lebih menekankan pada bagaimana cara mereka memperoleh laba apakah sudah dilakukan dengan nilainilai etika dan kejujuran. Selain itu ada nilai mental seperti kepuasan pelangganlah yang membuat mereka lebih termotivasi untuk pencapaian laba yang tinggi. Bagi mereka materi akan mengikuti dengan sendirinya. Ada makna spiritual juga di dalam kedua hubungan itu seperti motivasi karyawan timbul karena mengharap ridha Allah dan rasa sukur karena sudah mendapatkan pekerjaan sehingga bisa memberi nafkah buat keluarga dan orang sekitar. Makna-makna inilah yang sebetulnya yang bisa membuat suatu obyek menjadi lebih bermakna dalam pengertiannya.

Aksiologi adalah bagian dari filsafat yang mempersoalkan nilai terutama berhubungan dengan masalah atau teori umum formal mengenai nilai (Suriasumantri, 1993). Nilai merupakan sesuatu yang abstrak yang tidak dapat diukur secara statistik atau kuantitatif tetapi nilai menjadi sangat konkret dalam suatu kondisi atau situasi tertentu. Contoh: Di dalam Laporan Keuangan apakah laba yang diperoleh perusahaan sudah mencerminkan nilai keadilan (spiritual) dalam arti apakah perolehannya sudah disebarkan untuk kemaslahatan pegawai dari tingkat bawah sampai tingkat atas atau apakah laba yang diperoleh sudah mencerminkan nilai-nilai etika dan sesuai dengan prinsip syariah di dalam pencapaiannya.

Nilai yang bersifat abstrak merupakan sebuah konsep atau prinsip yang implementasinya kalau diterapkan oleh suatu subyek dapat menimbulkan persamaan pendapat atau sikap namun juga dapat menimbulkan pertentangan atau perbedaan. Dasar timbulnya perbedaan atau pertentangan adalah masalah 
Driana Leniwati: Pengembaraan Akuntan Menuju Kesadaran Spiritual: Dilihat dari Perspektif Ontologi, Epistemologi, dan Aksiologi

selera atau perasaan. Ada beberapa ahli yang mengatakan bahwa nilai adalah sesuatu yang tidak dapat diperdebatkan tetapi nilai sangat diperlukan dalam segala hal apapun. Dengan adanya nilai sesuatu menjadi lebih bermakna. Makna yang berada dibalik sesuatu yang nampak. Makna yang luas bila kita mencoba untuk mempelajarinya lebih dalam. Contoh: nilai keadilan di dalam pendistribuan gaji karyawan di suatu perusahaan tidak hanya merupakan pemberian hak dari perusahaan atas kewajiban karyawan terhadap perusahaan tetapi bila dikaji lebih dalam ada makna spiritual yang melekat di dalamnya yaitu rasa syukur dan loyalitas terhadap perusahaan atas gaji yang diperoleh. Semua dilakukan dengan ikhlas dan sudah merupakan budaya bagi mereka untuk memberikan yang terbaik untuk perusahaan. Begitu juga perusahaan akan berusaha adil di dalam pendistribusian gaji, insentif dan tunjangan bagi karyawan sebagai hak dari karyawan tersebut atas kewajiban yang sudah dilaksanakan. Jadi ada hubungan yang "indah" antara manusia dengan manusia yaitu pihak manajemen perusahaan dengan karyawan. Contoh lain: Akuntansi keperilakuan lahir di dalam perkembangan ilmu akuntansi dengan mengadopsi bidang-bidang ilmu lainnya seperti ilmu psikologi khususnya psikologi kognitif, antropologi dan sosial. Akuntansi keperilakuan hadir karena mendesaknya kebutuhan akuntansi dan pentingnya manusia (akuntan dan auditor) dalam bidang akuntansi lebih tepatnya sistem informasi akuntansi. Keberhasilan suatu sistem akuntansi tidak lepas dari perilaku manusia sebagai pemakai dan yang memberikan responnya. Dengan demikian akuntansi tidak hanya mempertimbangkan manusia sebagai "benda mati" tetapi juga memanusiakan manusia atau memberi nilai kepada manusia di dalam interaksi realitas sosialnya.

Selain itu makna nilai juga bisa terjadi antara hubungan antara manusia dengan alam. Manusia selalu tergantung pada alam dalam kehidupan sehariharinya terutama dalam memenuhi kebutuhan dasar manusia seperti makan, minum dan lain sebagainya. Semua diperoleh dari alam. Ketika manusia mendirikan usaha pun tidak terlepas dari alam. Tanah tempat manusia mendirikan perusahaan itu dari alam. Oleh karena itu sudah sepantasnya manusia berterimakasih kepada alam atau lingkungan dimana dia berada dengan memberikan makna nilai kepada alam. Contoh: akuntansi lingkungan 
Driana Leniwati: Pengembaraan Akuntan Menuju Kesadaran Spiritual: Dilihat dari Perspektif Ontologi, Epistemologi, dan Aksiologi

hadir di dalam memaknai hubungan manusia dengan alam. Latar belakang pentingnya akuntansi lingkungan pada dasarnya menuntut kesadaran penuh perusahaan-perusahaan maupun organisasi lainnya yang telah mengambil manfaat dari lingkungan. Penting bagi perusahaan-perusahaan atau organisasi lainnya agar dapat meningkatkan usaha dalam mempertimbangkan konservasi lingkungan secara berkelanjutan. Banyak perusahaan besar industri dan jasa yang kini menerapkan akuntansi lingkungan. Tujuannya adalah meningkatkan efisiensi pengelolaan lingkungan dengan melakukan penilaian kegiatan lingkungan dari sudut pandang biaya (environmental costs) dan manfaat atau efek (economic benefit).

Makna nilai lain adalah hubungan manusia dengan Tuhan. Manusia pada dasarnya adalah hamba Allah yang akan selalu mencari Tuhannya dan pada akhirnya akan kembali kepada Tuhannya. Setiap kegiatan usaha yang berdasarkan spiritual akan memberikan nilai yang berbeda seperti rasa tenang, damai bagi karyawan atau perusahaan. Contoh: seorang auditor akan merasa lebih tenang dan damai bila memberikan opini Wajar Tanpa Pengecualiaan yang dilandasi dengan nilai kejujuran atau seorang nasabah bank akan merasa lebih tenang bila bagi hasil atas investasi uangnya yang ada di bank sesuai dengan prinsip syariah dan masih banyak lagi contoh lainnya.

Akuntansi Syariah hadir di dalam perkembangan ilmu akuntansi untuk memberikan makna nilai terhadap akuntansi dan lingkungan sekitar. Penerapan nilai-nilai syariah sebagai pengganti nilai-nilai materi yang bersifat duniawi hadir untuk "menyejukkan" jiwa manusia yang rindu akan Tuhannya. Nilai-nilai yang memberikan makna yang menyentuh jiwa dianggap bisa memberikan ketenangan dan kedamaian. Materi bukan merupakan satu-satunya tujuan.

\section{HIPOTESIS}

Berdasarkan uraian literatur tersebut diatas, maka dapat dirumuskan hipotesis pada penelitian ini sebagai berikut:

H1: Peran etika dalam akuntansi sangat dibutuhkan guna mengembalikan akuntansi kepada dasar filsafat ilmu dalam tinjauan ontologi, epistemologi, dan aksiologi. 
Driana Leniwati: Pengembaraan Akuntan Menuju Kesadaran Spiritual: Dilihat dari Perspektif Ontologi, Epistemologi, dan Aksiologi

H2: Konsep kesadaran diri akuntan perlu disinergikan melalui interaksi dengan manusia, alam dan Tuhannya.

\section{METODE}

Penelitian deskriptif kualitatif ini menggunakan metode analisis perpaduan antara disciplined comparative dengan heuristic case studies. Blaikie dalam Kamayanti (2016) menjelaskan disciplined comparative merupakan studi kasus yang bertujuan membandingkan kasus yang dipelajari dengan teori yang mapan, sementara heuristic case studies bertujuan memformulasikan teori dengan cara menarik simpulan dari kasus tersebut lalu menambahkan studi dengan kasus lain untuk menarik generalisasi atas fenomena.

Penelitian ini meninjau akuntansi dari perspektif ontologi, epistemologi, aksiologi dengan mengkaitkannya pada praktik akuntansi modern saat ini. Kemudian mensinergikan kesadaran diri yang dimiliki akuntan dalam hubungannya dengan manusia, alam dan Tuhannya.

\section{HASIL DAN PEMBAHASAN}

\section{Peran Etika Dalam Akuntansi}

Corner (2009) menjelaskan bahwa etika merupakan sesuatu yang sangat penting di di dalam akuntansi karena dengan etika kita akan dibantu untuk mengetahui kelemahan moralitas diri kita, masyarakat dan bangsa serta sejauh mana moralitas dan norma yang mendasarinya. Etika adalah pembahasan mengenai baik buruk, benar atau salah, pantas atau tidak pantas, etis dan tidak etis serta yang seharusnya dilakukan dan tidak dilakukan. Etika mempelajari tatanan konsep yang melahirkan kewajiban melaksanakan yang baik, yang wajib, dan yang pantas. Kalau sesuatu tidak dijalankan berarti akan mendatangkan kerugian atau keburukan bagi manusia. Langeveld berpendapat bahwa aksiologi terdiri atas dua hal utama: etika dan estetika. Etika merupakan bagian filsafat penilaian yang membicarakan perilaku seseorang, sedangkan estetika adalah bagian filsafat tentang nilai dan penilaian yang memandang karya manusia dari sudut indah dan buruk.

Dalam filsafat terdapat beberapa persoalan nilai (etika) yaitu pertama, idealisme etis adalah aliran filafat yang menyakini hal-hal sebagai berikut: 1 . 
Driana Leniwati: Pengembaraan Akuntan Menuju Kesadaran Spiritual: Dilihat dari Perspektif Ontologi, Epistemologi, dan Aksiologi

Adanya suatu skala, asas-asas moral atau aturan-aturan untuk bertindak, 2 . Lebih mengutamakan hal-hal yang bersifat spiritual ataupun mental daripada yang bersifat inderawi atau kebendaan, 3. Lebih mengutamakan kebebasan moral daripada ketentuan kejiwaan atau alami, 4. Lebih mengutamakan hal yang umum daripada hal yang khusus. Kedua, deontologisme etis yang menyatakan bahwa sesuatu tindakan dianggap baik tanpa disangkutkan dengan nilai kebaikan sesuatu hal, yang menjadi dasar moralitas adalah kewajiban. Sesuatu dikatakan wajib secara moral, tanpa memperhitungkan akibat-akibat yang ditimbulkannya. Ketiga, etika teleologi, merupakan bagian dari etika aksiologis yang membuat ketentuan bahwa kebaikan atau kebenaran suatu tindakan sepenuhnya bergantung pada sesuatu tujuan atau sesuatu hasil. Keempat, hedonisme, menganjurkan manusia untuk mencapai kebahagiaan didasarkan pada kenikmatan, kesenangan. Sebagaimana Cyrenaic bahwa hidup yang baik adalah memperbanyak kenikmatan melalui kenikmatan indera dan kenikmatan intelek. Kelima, Utilitarisme, adalah pandangan yang menyatakan bahwa tindakan yang baik adalah tindakan yang menimbulkan kenikmatan atau kebahagiaan yang sebesar-besarnya bagi manusia sebanyak-banyaknya.

Persamaan dasar akuntansi Asset $=$ Kewajiban + Ekuitas, yang dipopulerkan oleh Luca Pacioli, sarat dengan nilai dan moralitas. Persamaan tersebut mengandung nilai kejujuran dengan aset sebagai wujud kekayaan perusahaan di satu sisi dan kewajiban serta ekuitas menjelaskan kekayaan tersebut berasal darimana. Jika persamaan tersebut hanya dipandang sebagai teori atau fakta belaka tanpa dilandasi oleh nilai kejujuran, keseimbangan kedua sisi bisa dicapai meskipun dengan berbagai manipulasi yang merugikan pihak lain. Nilai-nilai yang terkandung di dalam akuntansi tersebut sangat mungkin akan berubah dengan perubahan lingkungan sosial karena akuntansi memang merupakan produk dari relaitas sosial.

Akuntansi dan akuntan dalam konteks kontemporer saat ini selalu melihat pada realitas yang obyektif, ilmiah, materialistik kuantitatif, dan gagasan yang bebas nilai (value free). Peran para ilmuwan dan badan regulator sangat dituntut untuk menjaga proses reinforcement terhadap nilai-nilai agar tidak mengalami degradasi, sehingga diharapkan perubahan nilai akibat pengaruh lingkungan cenderung mengutamakan tata nilai sebelumnya (Van Buren \& Greenwood, 
Driana Leniwati: Pengembaraan Akuntan Menuju Kesadaran Spiritual: Dilihat dari Perspektif Ontologi, Epistemologi, dan Aksiologi

2013). Akuntansi pada dasarnya praktik moral dan diskursif, oleh sebab itu pengembangan praktik akuntansi secara ideal perlu dilakukan dengan penuh tangung jawab.

\section{Konsep Diri dan Hakekat Akuntan: Kesadaran Diri Akuntan Menuju Tuhannya}

Langkah pertama dalam persepsi diri akuntan adalah menyadari diri akuntan sendiri, yaitu mengungkap siapa dan apa akuntan ini dan sesungguhnya menyadari siapa diri akuntan. Konsep diri merupakan susunan kesadaran individu mengenai keterlibatan khusus dalam seperangkat hubungan sosial yang sedang berlangsung atau dalam suatu komunitas yang terorganisir (William, 1997). Mead dalam Krishna (2001) memandang diri itu berkembang dari keadaan yang serupa yang mewujudkan rohani yaitu kemunculan simbolsimbol signifikan dari tindakan-tindakan sosial. Diri sebagai obyek sosial berarti bahwa individu itu memperoleh makna yang diartikan oleh orang lain disekelilingnya.

Kesadaran diri seseorang yang membuat seseorang untuk melakukan tindakan (Pujol \& Beloucif, 2016). Sama seperti profesi lainnya pada umumnya, beberapa akuntan termotivasi terhadap profesi yang dijalaninya karena kesadaran diri yang mereka miliki. Setiap akuntan memiliki kesadaran diri yang berbeda-beda terhadap profesi mereka. Beberapa akuntan termotivasi karena spiritual, aktualisasi ilmu dan materi. Spiritual dikarenakan mereka ingin pekerjaannya menjadi sebuah ibadah dan berbuat jujur kepada masyarakat terhadap pekerjaan yang dilakukannya. Sedangkan aktualisasi ilmu adalah karena profesi akuntan selalu merasa bertanggung jawab akan keilmuannya dan ingin memanifestasikan dalam profesinya, maka tidak heran banyak dosen yang menjadi seorang Akuntan Publik juga. Secara materi, banyak orang yang ingin menjadi akuntan karena melihat bahwa pekerjaan akuntan ini adalah hal yang menjanjikan dalam bidang materi. Keinginan menjadi akuntan dari dirinya sendiri bukanlah sebuah kesadaran yang dipaksakan, melainkan telah terpatri dalam dirinya untuk mengabdi menjadi seorang akuntan sesuai dengan tingkat kesadaran yang dimiliki. 
Driana Leniwati: Pengembaraan Akuntan Menuju Kesadaran Spiritual: Dilihat dari Perspektif Ontologi, Epistemologi, dan Aksiologi

Akuntansi dalam perspektif ontologi, epistomologi dan aksiologi mempertanyakan apa hakikat ilmu akuntansi dan bagaimana seharusnya ilmu akuntansi itu? Pertanyaan tersebut mengandung makna yang dalam sebenarnya mau di bawa kemana akuntansi itu? Sebagaimana kita ketahui akuntansi yang kita pakai sekarang merujuk kepada akuntansi kapitalis dimana di dalam akuntansi itu hanya sifat material yang selalu dikedepankan. Akuntansi yang sekarang ini sarat dengan nilai-nilai kapitalis, sekuler dan egoistis. Semua memberikan apresiasi kepada keduniawian dan menyingkirkan agama dari perhatian. Bila diperhatikan produk dari akuntansi seperti: Laporan Laba Rugi yang memuat keuntungan dari hasil usaha suatu bisnis entities, Laporan Arus Kas yang berisi informasi aliran kas suatu entitas dalam suatu periode dan lainnya. Semua dibuat secara kuantitatif dengan pengukuran dalam suatu satuan mata uang. Dengan produk akuntansi yang sedemikian rupa ditambah dengan manusia yang terlahir sebagai "binatang ekonomi" maka bisa diduga kemana arah dari suatu entitas dalam menjalankan usahanya.

Akuntansi sendiri sebenarnya artinya adalah menghitung atau mempertanggungjawabkan. Akuntansi adalah proses mencatat, mengklasifikasi, meringkas, mengolah dan menyajikan data, transaski serta kejadian yang berhubungan dengan keuangan. Informasi yang tertera pada Laporan Keuangan inilah yang nanti akan digunakan oleh pihak-pihak yang berkepentingan untuk pengambilan keputusan. Sebagai Laporan pertanggungjawaban maka sudah seharusnya akuntansi bernilai kebenaran, terbuka dan jujur. Bagaimana akuntansi mencapai kebenaran yang hakiki yang bisa memberikan ketenangan dan kedamaian semua pihak yang terlibat di dalamnya sehingga semua merasakan keadilan dan ketenangan jiwa dalam melakukan pekerjaannya.

Pemikiran terhadap kriteria kebenaran pengetahuan akuntansi dan bagaimana mencapai kebenaran yang hakiki akuntansi memunculkan ilmu akuntansi yang lebih bernilai. Pemikiran bahwa akuntansi sarat dengan nilai agama, moral, mental dan spiritual disamping material itulah yang menumbuhkan ilmu akuntansi baru. Ada beberapa ilmu akuntansi yang muncul sebagai bentuk rasa dari "kebentrokan" dari akuntansi kapitalis yang ada. Sosial Responsibility Accounting, Akuntansi Lingkungan, Akuntansi Syariah yang lebih mengedepankan nilai-nilai lain selain nilai materi maka hakekat ilmu akuntansi 
Driana Leniwati: Pengembaraan Akuntan Menuju Kesadaran Spiritual: Dilihat dari Perspektif Ontologi, Epistemologi, dan Aksiologi

sebenarnya sudah mengarah kepada kemaslahatan umat dalam aartian akuntansi tidak dipandang sebagai ilmu kapital yang hanya mengedepankan duniawi tetapi juga mementingkan masyarakat sosial dan spiritualis yang lebih mengarah kepada kebaikan dunia akhirat.

\section{KESIMPULAN}

Konsep kesadaran diri manusia secara hierarki menentukan kualitas hidup manusia. Kesadaran diri yang tertinggi adalah kesadaran diri spiritual yang mana materi bukan menjadi fokus utama melainkan ketenangan jiwa yang bertumpu kepada Tuhan Yang Maha Esa.

Ilmu akuntansi yang ditelaah berdasarkan filosofi dasar yakni ontologi, epistemologi dan aksiologi akan mengarahkan kepada hakikat ilmu sekaligus memberikan paradigma baru dalam perkembangan ilmu akuntansi ditengah arus mainstream sekulerisme dunia. Untuk kedepannya diharapkan perilaku akuntan mulai memasukkan unsur spiritual dan religi serta hakikat ilmu akuntansi dalam menjalankan profesi akuntan sehingga pertanggungjawaban profesi bukan hanya bersifat horizontal kepada para stakeholder, namun juga bertanggungjawab secara vertikal kepada Tuhan Yang Maha Esa. Pola pikir baru ini diharapkan dapat memberikan dampak positif bagi profesi akuntan secara khusus dan kepada dunia bisnis secara umum.

\section{DAFTAR PUSTAKA}

Bouckaerti, L \& Zsolnai, L. (2012). Spirituality and Business: An Interdisciplinary Overview. Society and Economy 34 (3), pp. 489-514.

Brophy, M. (2015). Spirituality Incorporated: Including Convergent Spiritual Values in Business. Business Ethics 132:779-794.

Corner, P, D. (2009). Workplace Spirituality and Business Ethics: Insights from an Eastern Spiritual Tradition. Journal of Business Ethics 85:377-389.

Driscoll, C \& McKee, M. (2007). Restorying a Culture of Ethical and Spiritual Values: A Role for Leader Storytelling. Journal of Business Ethics 73:205217. 
Driana Leniwati: Pengembaraan Akuntan Menuju Kesadaran Spiritual: Dilihat dari Perspektif Ontologi, Epistemologi, dan Aksiologi

Ewest, T, G. (2015). Sociological, Psychological and Historical Perspectives on The Reemergence of Religion and Spirituality within Organizational Life. Journal of Religion and Business Ethics.

Gotsis, G \& Kortezi, Z. (2008). Philosophical Foundations of Workplace Spirituality: A Critical Approach. Journal of Business Ethics 78:575-600.

Kamayanti, A. (2016). Metodologi Penelitian Kualitatif Akuntansi, Pengantar Religiousitas Keilmuan. Jakarta selatan: Yayasan Rumah Peneleh.

Krishna, A. (2001). Ilmu Medis \& Meditasi. Gramedia Pustaka Utama Jakarta.

Kulik, Brian W. (2005). Agency Theory, Reasoning and Culture at Enron: In Search of a Solution. Journal of Business Ethics 59: 347-360.

Mc Pherson, D. (2015). Homo Religiosus: Does Spirituality Have a Place in NeoAristotelian Virtue Ethics?. Religious Studies 51: 335-346. Cambridge University Press.

Meng, Y. (2016). Spiritual Leadership at The Workplace: Perspectives and Theories (Review). Biomedical Reports 5: 408-412, 2016408.

Pujol, N. Jobin, G. Beloucif, S. (2016). Spiritual Care is Not The Hospital's Business': A Qualitative Study on The Perspectives of Patients about The Integration of Spirituality in Healthcare Settings. Clinical Ethics.

Suriasumantri, Jujun S. (1993). Filsafat Ilmu: Sebuah Pengantar Populer. Jakarta: Pustaka Sinar Harapan.

Van Buren III, H.J. \& Greenwood, M. (2013). The Genesis of Employment Ethics. Business Ethics 117:707-719.

William, C, S. (1997). Spirituality and Ethics: Exploring The Connections, Theological Studies; Mar: 58, 1; Research Library pg. 109. 